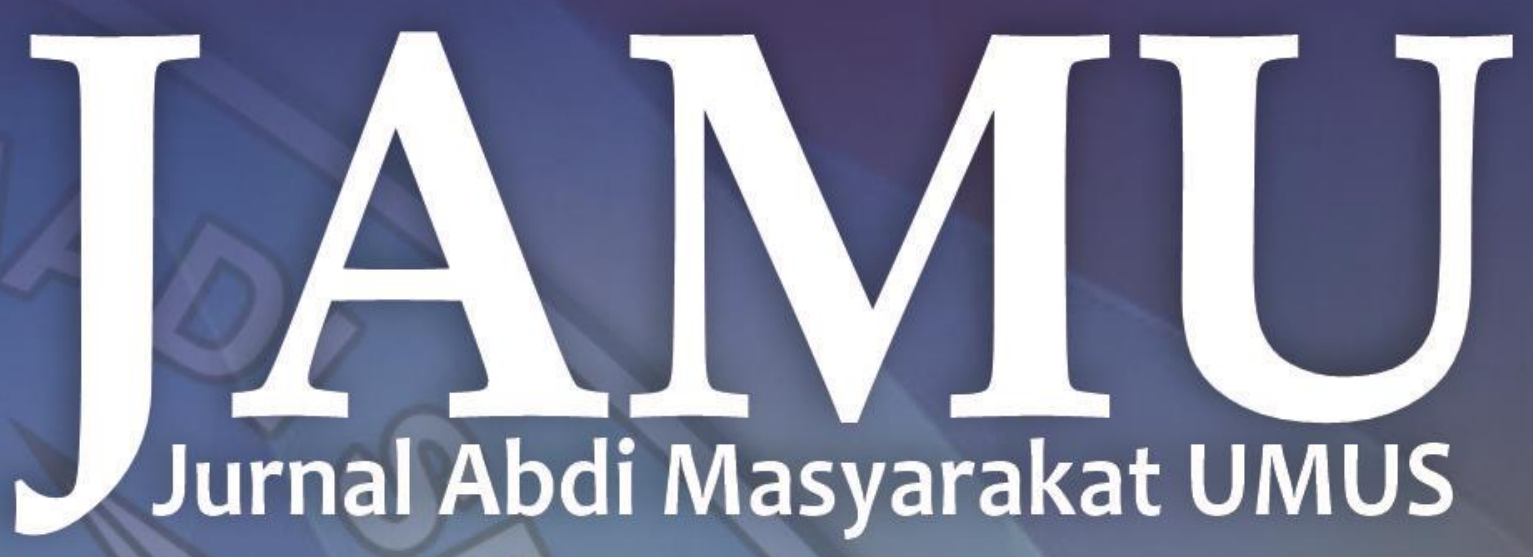




\section{EDITOR IN CHIEF}

Ubaedillah, M.Pd

\section{MANAGING EDITOR}

Harliana, ST., M.Cs

\section{PRINCIPAL CONTACT}

Rifatul Masrikhiyah, S.Tp., M.Si

\section{SUPPORT CONTACT}

Laelia Nurpratiwiningsih, M.Pd

\section{MITRA BESTARI (STAFF AHLI)}

Dr. Roby Setiadi, S.Kom., M.M (Universitas Muhadi Setiabudi, Brebes)

Otong Saeful Bachri, S.Kom., M.Kom (Universitas Muhadi Setiabudi, Brebes)

Dr. Moh. Toharudin, M.Pd (Universitas Muhadi Setiabudi, Brebes) Atikah Mumpuni, M.Pd (Universitas Muhadi Setiabudi, Brebes)

Dr. Heru Ismanto, S.Si., M.Cs (Universitas Musamus Merauke, Papua) Dr. Wuri Wuryandani, M.Pd (Universitas Negeri Yogyakarta)

Dr. Nanik Sulistyani, M.Si., Apt (Universitas Ahmad Dahlan, Yogyakarta)

Dina Rahayuning Pangestuti, S.TP., M.Gizi (Universitas Diponogoro) Jasanta Peranginangin, S.E., M.M (Sekolah Tinggi Pariwisata Sahid Surakarta)

Dr. Lili Karmela Fitriani, S.E., M.Si (Universitas Kuningan, Jawa Barat)

\section{PENANGGUNGJAWAB :}

Rektor Universitas Muhadi Setiabudi Brebes

\section{ALAMAT PENYUNTING:}

LP3M Universitas Muhadi Setiabudi Brebes.

Jalan Pangeran Diponogoro KM 2 Wanasari Brebes - Jawa Tengah 52252. Telp (0283) 6199000 


\section{JAMU}

Jurnal Abdi Masyarakat UMUS

\section{KATA PENGANTAR}

Assalamualaikum Wr, Wb

Puji syukur kehadirat Allah SWT atas anugrahnya sehingga jurnal edisi kali ini dapat terbit. Sebelumnya kami ingin mengucapkan terimakasih banyak kepada dosen/peneliti/profesi yang telah mengirimkan artikelnya kepada dewan redaksi untuk dapat dipublish pada jurnal yang kami kelola. Semua artikel yang masuk kepada dewan redaksi telah melalui proses review oleh mitra bestari dan tim dewan redaksi, segala proses revisi dan redaksional juga telah dilakukan oleh penulis sebelum jurnal ini diterbitkan. Segala bentuk kritik dan saran yang membangun dari pembaca / peneliti yang dikirimkan sangat kami harapkan demi melakukan pembenahan jurnal yang kami kelola. Akhir kata kami menghaturkan terimakasih banyak kepada semua pihak yang sudah terlibat dalam proses penerbitan jurnal ini.

Wassalamualaikum wr wb.

Ketua Dewan Redaksi 


\section{DAFTAR ISI}

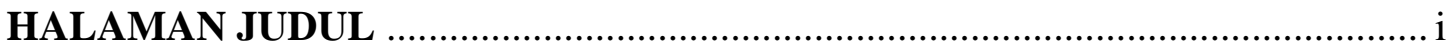

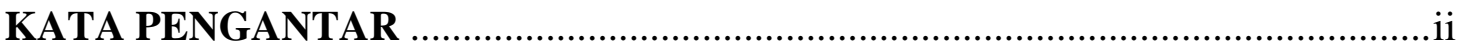

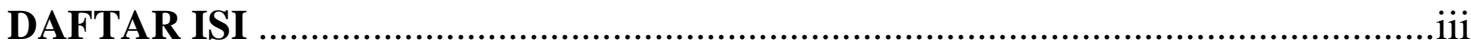

Pemberdayaan Anak Usia Sekolah Dalam Menumbuhkan Nilai Karakter Melalui Strategi Pembiasaan Di PPSA Tegal

Moh. Toharudin ${ }^{1}$, Laelia Nurpratiwiningsih ${ }^{2}$, Gian Fitralisma ${ }^{3}$

${ }^{(1,2)}$ Program Studi Pendidikan Guru Sekolah Dasar, Fakultas Keguruan dan Ilmu Pendidikan Universitas Muhadi Setiabudi

${ }^{3)}$ Program Studi Manajemen, Fakultas Ekonomi dan Bisnis, Universitas Muhadi Setiabudi) $\quad$ 1-7

Menstimulasi Kemampuan Berbicara Pada Anak Usia Dini Berbasis Media Dongeng Agnes Apryliana ${ }^{1)}$, Kiki Purwati ${ }^{2}$

${ }^{(1,2)}$ Program Studi Pendidikan Bahasa dan Sastra Indonesia, Fakultas Keguruan dan Ilmu Pendidikan, Universitas Muhadi Setiabudi)

Pemanfaatan E-Commerce Terhadap Penjualan Kendang Jimbe Blitar Harliana $^{1)}$, Roby Setiadii ${ }^{2}$, Otong Saeful Bachri ${ }^{3)}$, Khalid Iskandar ${ }^{4)}$, Gagas Prasetya ${ }^{5)}$ ${ }^{(1,3,5)}$ Program Studi Teknik Informatika, Fakultas Teknik, Universitas Muhadi Setiabudi ${ }^{2,4)}$ Program Studi Manajemen, Fakultas Ekonomi dan Bisnis, Universitas Muhadi Setiabudi) 15-20

Manajemen Tatakelola BUMDES: Mengelola Pemasaran Produk Andi Yulianto ${ }^{1)}$, Mukson ${ }^{2)}$, Otong Saeful Bachri ${ }^{3)}$, Slamet Bambang Riono ${ }^{4}$, Yenny Ernitawati ${ }^{5)}$ ${ }^{(1,2,4)}$ Program Studi Manajemen, Fakultas Ekonomi dan Bisnis, Universitas Muhadi Setiabudi ${ }^{5)}$ Program Studi Akuntansi, Fakultas Ekonomi dan Bisnis, Universitas Muhadi Setiabudi) ${ }^{3)}$ Program Studi Teknik Informatika, Fakultas Teknik, Universitas Muhadi Setiabudi)

Penggunaan Kartu Huruf dan Peramainan Mencari Kartu Huruf Untuk Peningkatan Pengenalan Huruf

Muhammad Toha ${ }^{1)}$, Ubaedillah ${ }^{2)}$, Farhan Saefudin Wahid ${ }^{3)}$, Laelia Nurpratiwiningsih ${ }^{4)}$, Mohamad Badrun Zaman ${ }^{5}$

${ }^{(1,2)}$ Program Studi Pendidikan Bahasa dan Sastra Indoensia, Fakultas Keguruan dan Ilmu Pendidikan, Universitas Muhadi Setiabudi,

${ }^{3,4)}$ Program Studi Pendidikan Guru Sekolah Dasar, Fakultas Keguruan dan Ilmu Pendidikan, Universitas Muhadi Setiabudi)

${ }^{3)}$ Program Studi Manajemen, Fakultas Ekonomi dan Bisnis, Universitas Muhadi Setiabudi) 
Menumbuhkan Sikap Sadar Lingkungan Bagi Anak Usia Sekolah Dasar

Laelia Nurpratiwiningsih $^{1)}$, Wildan Qosid ${ }^{2)}$, Ubaedillah ${ }^{3)}$

${ }^{(1,2)}$ Program Studi Pendidikan Guru Sekolah Dasar, Fakultas Keguruan dan Ilmu Pendidikan, Universitas Muhadi Setiabudi,

${ }^{(3)}$ Program Studi Pendidikan Bahasa dan Sastra Indonesia, Fakultas Keguruan dan Ilmu Pendidikan, Universitas Muhadi Setiabudi)

$34-41$

Peningkatan Pengetahuan Mengenai Manfaat Pangan Probiotik dan Prebiotik Bagi Kesehatan

Rifatul Masrikhiyah ${ }^{1)}$, Ubaedillah $^{2}$, Rifqi Ferry Balfas ${ }^{3)}$, Susi Yulianingsih ${ }^{4)}$

${ }^{(1,4)}$ Program Studi Ilmu Gizi, Fakultas Kesehatan, Universitas Muhadi Setiabudi,

${ }^{2)}$ Program Studi Pendidikan Bahasa dan Sastra Indonesia, Fakultas Keguruan dan Ilmu Pendidikan, Universitas Muhadi Setiabudi,

${ }^{3)}$ Program Studi Ilmu Gizi, Fakultas Ilmu Kesehatan, Universitas Muhadi Setiabudi)

$42-46$

\section{Pelatihan Wawancara Kerja Dalam Bahasa Inggris Bagi Siswa SMK Menggunakan}

Metode Demonstrasi

Ubaedillah $^{1)}$, Mukson $^{2)}$, Muhamad Toha ${ }^{3)}$, Rifatul Masrikhiyah ${ }^{4)}$, Laelia Nurpratiwiningsih ${ }^{5)}$

${ }^{(1,3)}$ Program Studi Pendidikan Bahasa dan Sastra Indonesia, Fakultas Keguruan dan Ilmu Pendidikan, Universitas Muhadi Setiabudi,

${ }^{2)}$ Program Studi Manajemen, Fakultas Ekonomi dan Bisnis, Universitas Muhadi Setiabudi,

${ }^{4)}$ Program Studi Ilmu Gizi, Fakultas Ilmu Kesehatan, Universitas Muhadi Setiabudi

${ }^{5}$ Program Studi Guru Sekolah Dasar, Fakultas Keguruan dan Ilmu Pendidikan, Universitas Muhadi Setiabudi) 


\title{
PEMANFAATAN E-COMMERCE TERHADAP PENJUALAN KENDANG JIMBE BLITAR
}

\author{
Harliana $^{* 1}$, Roby Setiadi ${ }^{2}$, Otong Saeful Bachri ${ }^{3}$ Khalid Iskandar $^{4}$ Gagas Prasetya $^{5}$ \\ 1,3,5 Program Studi Teknik Informatika, Fakultas Teknik, Universitas Muhadi Setiabudi Brebes, \\ Indonesia \\ ${ }^{2,4}$ Program Studi Manajemen, Fakultas Ekonomi dan Bisnis, Universitas Muhadi Setiabudi \\ Brebes, Indonesia \\ e-mail: ${ }^{* 1}$ harliana@umus.ac.id, ${ }^{2}$ roby.setiadi@umus.ac.id, ${ }^{3}$ otong.sb@umus.ac.id, \\ ${ }^{4}$ khalid.iskandar@umus.ac.id, ${ }^{5}$ gagas.prasetya@studentumus.ac.id
}

\begin{abstract}
Kendang jimbe is one of the souvenirs from Blitar. In 2019, Kendang Jimbe Wawan was able to meet consumer export demand from China by producing around 500 - 700 drums every day with a production process of only five days, starting from the process of turning, polishing, painting, carving to installing leather. During the Covid-19 epidemic, the production of drums in demand drastically decreased the demand for drums, one of which was the jimbe wawan drums in Tanggung Village. Through the activities carried out, we are trying to help Kendang Jimbe Wawan in marketing his products through internet media (ecommerce) with a B2C approach. Based on observations for 1 month, the demand for Jimbe Wawan drums was able to increase by about 3\% from the previous month's demand.
\end{abstract}

Kata kunci-kendang jimbe, marketing, e-commerce

\section{PENDAHULUAN}

Kota Blitar merupakan salah satu daerah di wilayah propinsi Jawa Timur yang secara geografis terletak diujung selatan Jawa Timur dengan ketinggian $156 \mathrm{~m}$ dari permukaan air laut, pada koordinat $112^{0} 14-112^{0} 28$ Bujur Timur dan $8^{0} 2-8^{0} 8$ lintang selatan tepatnya berada di tengah wilayah kabupaten Blitar, memiliki suhu udara cukup sejuk rata-rata $24^{\circ} \mathrm{C}-34^{\circ} \mathrm{C}$ karena Kota Blitar berada di kaki Gunung Kelud dan dengan jarak 160 $\mathrm{km}$ arah tenggara dari ibukota Propinsi Surabaya(Pemerintah Kota Blitar 2019).

Kehidupan masyarakat di Kota dan Kabupaten Blitar secara umum masih cukup kental akan adanya adat dan tradisi budaya Jawa. Dalam kesehariannya, masyarakat Blitar ada yang berpenghasilan sebagai petani, peternak, pedagang, pegawai negeri, karyawan swasta, wirausahaan, perajin dan pekerja lainnya. Salah satu bentuk aktivitas budaya yang dilakukan oleh sebagian masyarakat di Blitar adalah usaha kerajinan home indutri yang bernilai ekonomis serta menjadi asset budaya daerah setempat.

Salah satu daerah yang cukup terkenal dengan penghasil kendang jimbe adalah Kelurahan Tanggung, Kecamatan Kepanjen Kidul Kota Blitar. Industry dibidang kerajinan kendang jimbe ini paling banyak adalah home industry dengan tenaga kerja yang berasal dari keluarga. Kendang jimbe wawan merupakan salah satu pengrajin home industry yang bergerak pada produksi kendang jimbe di Blitar. Saat ini kendang jimbe wawan memproduksi kendang jimbe jenis lukis ataupun ukir dengan berbagai motif. Untuk ukuran, kendang jimbe wawan mampu memproduksi berbagai ukuran mulai dari yang memiliki tinggi $40 \mathrm{~cm}$ dengan diameter 19/20, tinggi $50 \mathrm{~cm}$ dengan diameter $21 / 23$ ataupun $24 / 25$, dan juga dengan tinggi $60 \mathrm{~cm}$ dengan diameter 27/28 
ataupun 29/30. Pada perkembangannya, kendang jimbe tidak hanya dikenal sebagai alat music tradisional yang berasal dari Afrika, tetapi juga sebagai salah satu hasil kerajinan tangan(Ida Rosita 2014).

Pada tahun 2019, kendang jimbe wawan mampu memenuhi permintaan ekspor konsumen dari china dengan memproduksi sekitar 500 - 700 kendang setiap hari dengan proses produksi hanya lima hari, mulai dari proses pembubutan, pemelituran, pengecetan, pengukiran hingga pemasangan kulit. Namun untuk proses produksi kendang jimbe wawan masih bergantung pada cuaca. Namun setelah pendemi covid-19 melanda, jumlah permintaan kendang jimbe wawan menurun drastis. Saat ini kendang jimbe wawan hanya mampu memproduksi 50 buah kendang untuk perbulan dengan cakupan pemasaran lokal. Hal ini disebabkan karena sudah tidak adanya lagi permintaan kendang jimbe dari pasar china, tiongkok, dan beberapa kawasan eropa lainnya sejak awal tahun 2020.

Berdasarkan analisis situasi, maka beberapa permasalahan yang terjadi pada mitra terangkum pada Tabel 1.

Table 1. Analisa permasalahan

\begin{tabular}{clc}
\hline No & Permasalahan mitra & $\begin{array}{c}\text { No } \\
\text { prioritas }\end{array}$ \\
\hline 1 & $\begin{array}{l}\text { Pemahaman tentang } \\
\text { pemasaran produk }\end{array}$ & Prioritas 1 \\
\hline 2 & $\begin{array}{l}\text { System penjualan }(e- \\
\text { commerce }) \text { produk }\end{array}$ & Prioritas 2 \\
\hline 3 & $\begin{array}{l}\text { Edukasi teknologi } \\
\text { system penjualan produk }\end{array}$ & Prioritas 3 \\
\hline
\end{tabular}

Melihat situasi kendang jimbe wawan, kami memprioritaskan pemahaman mengenai bagaimana melakukan strategi pemasaran kendang jimbe tersebut, baik secara online ataupun secara offline menjadi prioritas pertama. Selanjutnya untuk memenuhi pemasaran secara online, akan dibuatkan suatu website pemasaran dengan tujuan mengenalkan kendang jimbe wawan yang menjadi salah satu ciri khas Blitar kepada pengguna internet. Setelah system dibangun, maka prioritas terakhir adalah melakukan edukasi mengenai penggunaan system
Tujuan dalam kegiatan ini yaitu membantu kendang jimbe wawan dalam memasarkan produknya melalui suatu media internet, sehingga produksinya dapat meningkat.

\section{METODE PELAKSANAAN}

Agar solusi yang ditawarkan sejalan dengan tujuan dan permasalahan yang terjadi pada mitra, maka kami akan mencoba akan memberikan solusi:

a. Untuk pemasaran produk

Untuk permasalahan pemasaran produk, kami akan menerapkan system B2C (business to consumer) yaitu menjual produk secara online kepada pengguna akhir(Reza 2016). Kendang jimbe wawan, melihat suatu peluang pasar berdasarkan 3 faktor utama, yaitu lingkungan ekonomi, lingkungan budaya, dan lingkungan teknologi. Berdasarkan lingkungan ekonomi, maka suatu pasar pasti memelukan adanya daya beli, dimana daya beli akan bergantung pada pendapatan, harga, tabungan dan ketersediaan kredit. Sedangkan pemasar haruslah dapat memperhatikan dengan cermat tren utama dalam mementukan pendapatan dan pola pembelajaran konsumen(Kotler 2005)

b. Penjualan produk secara online

Pada kenyataanya kendang jimbe wawan tidak menentukan segmentasi pasar secara terperinci. Oleh karena itu kami akan menggunakan system pemasaran yang terhubung langsung dengan jaringan internet kepada siapapun dan dimanapun melalui media online website. E-Commerce merupakan suatu produk teknologi informasi yang menawarkan berbagai kemudahan bagi para pelaku bisnis yang dipandang sebagai model dari perdagangan dan bisnis global masa depan yang memanfaatkan secara optimal kemajuan teknologi telekomunikasi dan informasi(Tarmizi and Firmansyah 2020)

c. Edukasi 
Untuk edukasi, kami akan melakukan pelatihan mengenai tatacara penggunaan system dan maintenance terhadap system yang telah dibuat. Diharapkan pelaku kendang jimbe wawan, dapat lebih memahami karakteristik dari e-commerce baik dari sisi customer ataupun seller.

Untuk membantu dalam penyusunan kebutuhan berdasarkan prioritas, maka perlu adanya penyusunan kerangka kerja (framework) yang jelas terhadap tahapantahapannya. Rangkuman mengenai kerangka kerja tersebut terangkum pada Gambar 1.

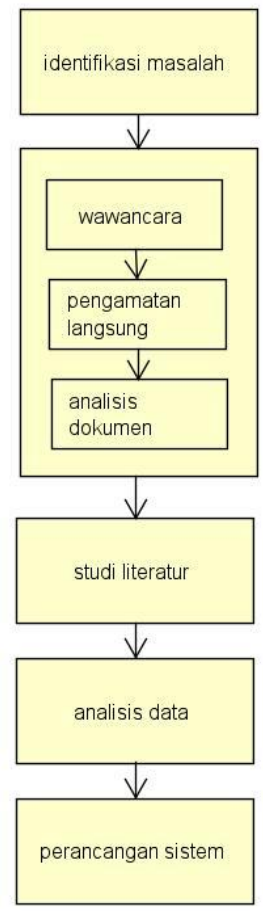

\section{Gambar 1. Alur pelaksanaan}

1. Identifikasi masalah

Pada tahapan ini, kami akan melakukan identifikasi masalah yang sedang terjadi melalui observasi langsung ke home industry kendang jimbe wawan dan melakukan wawancara langsung dengan owner.

2. Pengumpulan data

Untuk pengumpulan data kami melakukan wawancara dan observasi serta mengambil beberapa dokumen pendukung yang diperlukan. Pada tahap pengumpulan data akan dilakukan wawancara, pengamatan langsung, dan analisis dokumen. Wawancara dilakukan untuk mendapatkan sumber data utama untuk suatu penelitian baik dalam bentuk uraian ataupun kutipan langsung (Rijali 2019). Setelah itu dilakukan observasi atau pengamatan langsung terhadap penjelasan dari hasil wawancara tersebut. Untuk mendukung wawancara dan observasi tersebut, kami akan melakukan Analisa terhadap dokumen yang diperlukan dalam membuat system.

3. Studi literatur

Pada tahap ini kami akan mempelajari dan menerapkan mengenai teori-teori tentang dasar pengembangan system pemasaran secara online $(e-$ commerce).

4. Analisis data

Pada tahapan ini, kami akan mengumpulkan dan menganalisis data yang berkaitan dengan system pemesanan kendang jimbe secara online. Adapun data yang dibutuhkan adalah data yang berhubungan dengan penilaian yang digunakan dalam pemesanan produk.

5. Perancangan system

Pada tahap perancangan, kami akan menggunakan pendekatan secara protoype, dimana protoype merupakan suatu metode pendekatan dalam pengembangan sistem dengan membuat sebuah program secara cepat dan bertahap sehingga dapat langsung dievaluasi oleh pengguna(Fikriyya and Dirgahayu 2020).

Metode yang dilakukan dalam kegiatan PKM ini adalah:

a. Metode ceramah dan tanya jawab

Metode tanya jawab dilakukan untuk memberikan respon kepada pak wawan selaku pemilik home industry kendang jimbe wawan mengenai system B2C yang ditawarkan. Pada tahapan ini kami akan menjelaskan mengenai kelebihan system B2C dari sisi penjual dan dari sisi pembeli. Dari sisi penjual, system B2C memberikan keuntungan dengan dapat mempromosikan produk kendang 
jimbe secara luas, namun dengan transaksi yang dilakukan selama 24 jam penuh tanpa mengenal hari libur. Selain itu melalui system ini pak wawan dapat berinteraksi langsung dengan konsumen tanpa melalui perantara sehingga dapat meminimalisisr biaya pengeluaran.

b. Pengumpulan data

Pada tahapan ini, kami akan melakukan pengumpulan data-data yang diperlukan yang selanjutnya akan diolah menjadi suatu e-commerce.

c. Penyusunan modul penggunaan $e$ commerce

Setelah aplikasi dibangun, maka kami akan membuatkan suatu modul penggunaan aplikasi e-commerce. Modul ini diharapkan dapat membantu dan mempermudah pak wawan dalam mengoperasikan aplikasinya.

\section{HASIL DAN PEMBAHASAN}

Saat ini proses penjualan kendang jimbe wawan masih dilakukan secara manual, yaitu melalui pihak ketiga. Namun karena adanya pendemi covid-19 yang melanda seluruh dunia termasuk china, tiongkok, dan beberapa kawasan eropa lainnya maka mau tidak mau, wawan sebagai pemilik home industry kendang jimbe wawan melakukan beberapa terobosan penting. Untuk membantu memasarkan kendang jimbe wawan, kami akan membantu dalam proses pemasaran secara online melalui B2C. Kami lebih memilih media pemasaran secara online karena saat ini internet sudah menjadi salah satu media komunikasi pemasaran langsung karena konsumen dan penjual dapat berinteraksi langsung mengenai pesanan ataupun permintaan informasi lainnya mengenai produk yang ditawarkan. Berdasarkan hal tersebut, maka kami menawarkan kepraktisan dalam berbelanja kendang jimbe melalui suatu website. Adapun strategi pemasaran kendang jimbe wawan secara online terangkum pada Gambar 2.

\section{Strategi pemasaran}

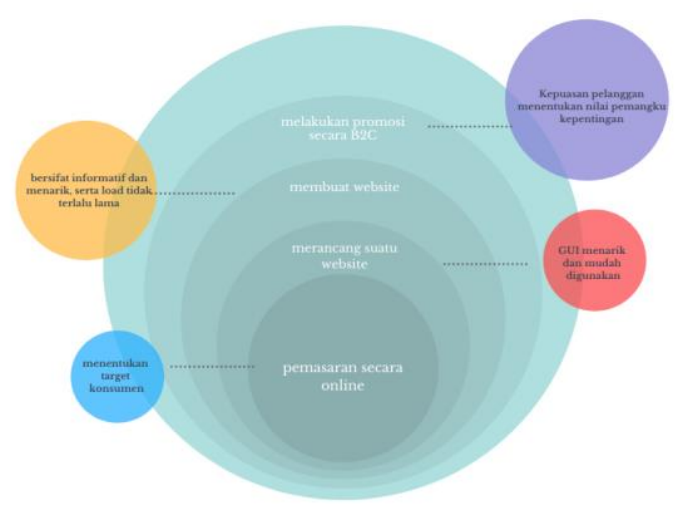

Gambar 2. Strategi pemasaran

Setelah system B2C disetujui, maka kami akan melakukan sosialisasi mengenai penerapan B2C terhadap produk kendang jimbe. Gambar 3 merupakan sosialisasi saat penerapan $\mathrm{B} 2 \mathrm{C}$.

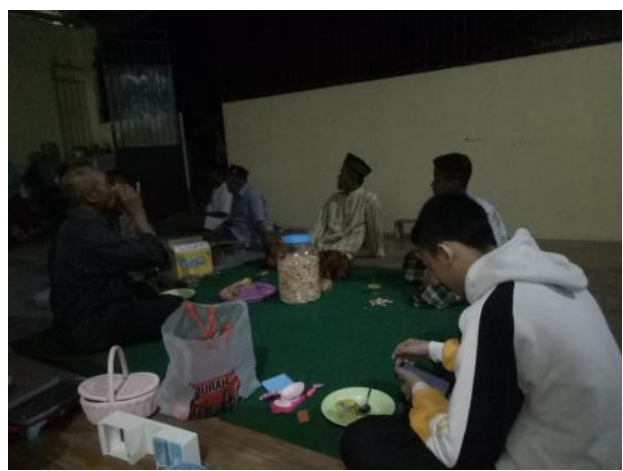

Gambar 3. Sosialisasi penerapan B2C

Kami menggunakan system B2C karena kami melihat kendang jimbe dapat diproduksi sesuai dengan spesifikasi permintaan konsumen dan produsen (dalam hal ini kendang jimbe wawan) harus siap terhadap permintaan tersebut. Selain itu juga melalui B2C kendang jimbe wawan dapat membidik langsung konsumen akhir. Selain itu transaksi $e$-commerce secara B2C menyerupai model ritel tradisional, dimana bisnis menjual barang langsung kepada konsumen namun dijalankan dengan platform online.

Beberapa rekomendasi yang kami berikan terhadap penerapan B2C kepada kendang jimbe wawan adalah adanya penekanan terhadap kualitas produk, bekerjasama melalui jasa ekspedisi melalui system pelayanan one day delivery atau on 
demand, serta adanya kemudahan dalam proses pembayaran seperti cash on delivery untuk beberapa daerah tertentu.

Setelah penerapan B2C diterima baik oleh pak wawan dan para pengrajin, maka selanjutnya adalah proses pembuatan aplikasi website. Sebelum dibuatkannya suatu website, kami akan menentukan target konsumen untuk penjualan kendang jimbe wawan. Target tersebut adalah para seniman, kolektor alat music, atau bahkan konsumen luar negri. Karena kendang jimbe banyak diminati oleh konsumen luar negri, maka dalam hal perancangan website kami akan menggunakan dua Bahasa, yakni Bahasa Inggris dan Bahasa Indonesia. Selanjutnya untuk GUI halaman utama website terlihat pada Gambar 4.

Menu produk akan digunakan untuk memberikan informasi mengenai berbagai jenis produk kendang jimbe yang dihasilkan oleh kendang jimbe wawan. Petunjuk pembelian digunakan untuk memberikan informasi mengenai tatacara pembelian kendang jimbe wawan melalui website. Dalam menu petunjuk pembelian, konsumen akan mendapatkan sub menu berupa cara mendaftarkan diri sebelum memesan produk, cara pemesanan produk, cara pembayaran, serta cara konfirmasi pembayaran tersebut. Adapun sub-sub menu tersebut digunakan untuk memberikan informasi mengenai alur bagaimana caranya konsumen mendaftarkan diri / memesan produk / melakukan pembayaran / konfirmasi pembayaran melalui website sebelum / setelah melakukan pemesanan produk

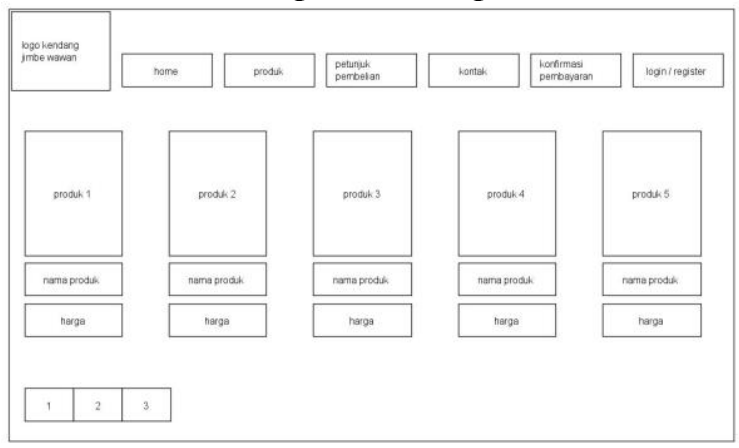

Gambar 4. Halaman utama

Sedangkan menu kontak digunakan untuk memberikan informasi mengenai beberapa kontak yang dapat dihubungi langsung oleh konsumen. Pada menu ini, kami akan menampilkan no whatsapp, email, instragram dan facebook yang bisa dihubungi. Untuk menu konfirmasi pembayaran digunakan untuk memverifikasi pembayaran yang telah dilakukan konsumen. Dan menu login / register digunakan oleh konsumen untuk mendaftarkan diri sebelum melakukan transaksi atau untuk login saat ingin bertransaksi pada website.

Ketika konsumen memilih salah satu produk, maka konsumen akan diberikan informasi mengenai spasifikasi detail produk kendang jimbe berupa ukuran diameter, tinggi kendang jimbe, jenis ukiran, bahan kayu, jenis kulit, dan tali pada jimbe. Apabila konsumen memiliki keinginan diluar spesifikasi yang diberikan, maka konsumen dapat menuliskan spesifikasi tersebut dalam kolom catatan. Rincian mengenai desain halaman produk terdapat pada Gambar 5.

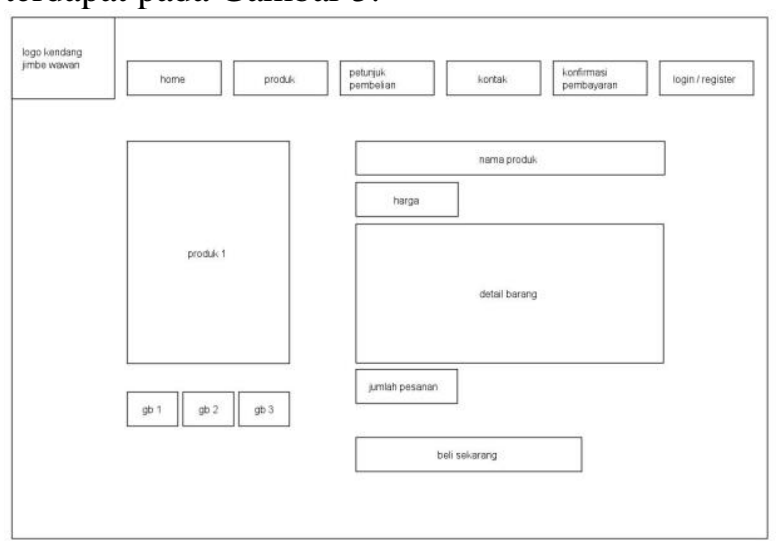

Gambar 5. Form pemesanan produk

Setelah website berhasil diimplementasikan berdasarkan GUI yang telah dirancang, maka kami akan mulai melakukan promosi penjualan secara B2C.

\section{KESIMPULAN}

Berdasarkan hasil kegiatan yang telah kami lakukan, maka didapatkan bahwa penerapan teknologi khususnya pembuatan suatu website, mampu 
membantu promosi dan pemasaran kendang jimbe wawan. Selain itu system B2C mampu diterapkan dalam proses pemasaran karena dapat mengakomodir keinginan konsumen terhadap jenis dan spesifikasi kendang jimbe

\section{DAFTAR PUSTAKA}

Fikriyya, Ashfa, and Raden Teduh Dirgahayu. 2020. "Implementasi Prototyping Dalam Perancangan Sistem Informasi Sekolah Desa Pendar Foundation Yogyakarta." Automata 1(2).

Ida Rosita, \& Siti Sunrowiyati. 2014. "ANALISIS BIAYA OVERHEAD PABRIK TERHADAP PENENTUAN BEBAN POKOK PRODUKSI (STUDI KASUS PADA UD. KARYA MANDIRI BLITAR)." Jurnal Kompilek.

Kotler. 2005. "Manajemen Pemasaran. In: Manajemen Pemasaran." In Edisi Millenium, Jilid 1,.

Pemerintah Kota Blitar. 2019. "Gambaran Umum Kota Blitar." : 1-5. https://www.blitarkota.go.id/index.ph $\mathrm{p} / \mathrm{id} /$ halaman/gambaran-umum.

Reza, Faizal. 2016. "Strategi Promosi Penjualan Online Lazada.Co.Id." Jurnal Kajian Komunikasi 4(1): 6474.

http://journal.unpad.ac.id/jkk/article/vi ew/6179/4283.

Rijali, Ahmad. 2019. "Analisis Data Kualitatif." Alhadharah: Jurnal Ilmu Dakwah 17(33): 81.

Tarmizi, and J Firmansyah. 2020. "Sistem Penjualan Online Dengan Strategi Pemasaran Cross Selling Online Sales System With Cross Selling Marketing Strategy." Journal of Informatics and Computer Science 6(1): 11-16. http://jurnal.uui.ac.id/index.php/jics/ar ticle/view/737. 